\title{
EFFECTS OF FRUIT AND VEGETABLE CONSUMPTION, A SOCIO-ECONOMIC FACTOR OF ADOLESCENT OBESITY IN SURAKARTA CITY
}

\author{
Emita Dewi Lilis Angkasa Wati ${ }^{1)}$, Eti Poncorini Pamungkasari ${ }^{2)}$, \\ Ruben Dharmawan²) \\ 1)Masters Program in Public Health, Sebelas Maret University \\ 2)Faculty of Medicine, Sebelas Maret University
}

\begin{abstract}
Background: Adolescent obesity is an escalating global epidemic. It is estimated that $70 \%$ of obese teenagers aged 10 to 13 years are at risk of being obese over their life course. Obesity becomes a problem because it brings complications and it is associated with accelerated atherosclerosis, increased incidences of degenerative diseases, such as cardiovascular diseases, stroke and diabetic. The purpose of this study was to decribe the effects of fruit and vegetable consumption, a socio-economic factor of adolescent obesity.

Subjects and Method: The study was an analytical observation using case control design. The study was conducted in Surakarta city in February to March 2017, and it involved 140 subjects. Samples were collected using purposive sampling technique with fixed disease sampling. The independent variables under the study were fruit and vegetable consumption, mothers' education, family income, and age. The dependent variable of the study was obesity. Data was collected using questionnaire, information on the fruit and vegetable consumption was gathered through a 24-hour food recall, and weight and height were measured. The data was analyzed using path analysis.

Results: The statistic finding showed that obesity was affected by fruit and vegetable consumption $(b=-0.01 ; \mathrm{SE}<0.01 ; \mathrm{p}=0.010)$, and age $(\mathrm{b}=-0.28$; $\mathrm{SE}=0.14 ; \mathrm{p}=0.048$ ), and the fruit and vegetable consumption was affected by the mothers' education $(b=14.118 ; \mathrm{SE}=9.39 ; \mathrm{p}=0.133)$ and family income $(b=-0.35 ; \mathrm{SE}=0.44 ; \mathrm{p}=0.431)$.

Conclusion: Fruit and vegetable consumption and age are directly associated with adolescent obesity. Mothers' education and family income are indirectly associated with adolescent obesity.
\end{abstract}

Keywords: Adolescent, fruit and vegetable consumption, socio-economic, obesity

Correspondence: Emita Dewi Lilis Angkasa Wati. Masters Program in Public Health, Sebelas Maret University, Jl. Ir. Sutami 36 A, Surakarta 57126, Central Java, Indonesia. Email: Taurus.emita92@gmail.com.

Mobile: +6281252794863. 